\title{
Correlations between serum proteins modified by acetaldehyde and biochemical variables in heavy drinkers
}

\author{
S N WICKRAMASINGHE,* D H MARJOT, $†$ S B ROSALKI, $\ddagger$ R S FINK $\uparrow$
}

From the *Department of Haematology, St Mary's Hospital Medical School, London, the $†$ Regional Alcoholism and Drug Dependence Unit, Ealing Hospital, the $\ddagger$ Department of Chemical Pathology and Human Metabolism, Royal Free Hospital and School of Medicine, and the ๆDepartment of Chemical Pathology, West Middlesex University Hospital, Isleworth, Middlesex

SUMMARY A strong and highly significant correlation was observed between serum aspartate transaminase (AST) activity and an index of the cytotoxic activity associated with serum proteins modified by acetaldehyde in a group of 24 heavy drinkers. A weaker but significant correlation $(R=0.564, p=0.008)$ was found between total serum creatine kinase activity and this index of serum cytotoxicity.

As it is likely that the concentration of circulating modified protein was largely determined by the quantity of free acetaldehyde generated in the liver and that the AST activity was mainly derived from damaged hepatocytes, the data indicate a correlation between hepatic acetaldehyde generation and hepatocyte damage. This correlation may indicate either that increased quantities of acetaldehyde are released by damaged hepatocytes or that acetaldehyde is hepatotoxic in vivo. As only the creatine kinase isoenzyme present in skeletal muscle (CK-MM) was demonstrable in the serum in all but one of our patients, the data also suggest that circulating modified serum proteins may be toxic towards skeletal muscle cells.

The mechanisms underlying tissue damage induced by alcohol are still uncertain. It is generally accepted that the susceptibility of the liver to damage induced by ethanol is related to the fact that over $90 \%$ of ethanol metabolism takes place in this organ. ${ }^{1}$ More recently it has been suggested that damage to certain extrahepatic tissues may be a consequence of the ability of tissue macrophages to metabolise ethanol at substantial rates. ${ }^{2-5}$ The eventual mediators of hepatic and extrahepatic tissue damage which have been proposed include acetaldehyde, ${ }^{67}$ free radicals, ${ }^{8-10}$ antibodies against neoantigens induced by alcoholism, ${ }^{11}$ and serum proteins modified by acetaldehyde. ${ }^{5}$ The last of these propositions is based on the finding that the consumption of ethanol is followed by the appearance of circulating acetaldehyde protein complexes which are cytotoxic towards various cell types in vitro. ${ }^{12}{ }^{13}$ In this study we investigated the importance of circulating cytotoxic proteins in the pathogenesis of tissue damage resulting from alcohol abuse in a group of heavy drinkers by correlating two indices of the Accepted for publication 6 October 1988 cytotoxic activity of serum proteins with various biochemical markers of hepatic and extrahepatic tissue damage.

\section{Material and methods}

Twenty two male and two female patients were studied on the morning of admission to the Regional Alcoholism and Drug Dependency Unit, St Bernards Hospital, Ealing. All had consumed excessive quantities of ethanol and had continued to drink heavily until admission to the Unit. Table 1 gives demographic details. Clinical history and blood samples were obtained before administration of drugs (chlormethiazole, phenytoin) for suppression of the withdrawal reaction.

Blood specimens were collected using the vacutainer system. An aliquot was mixed with ethylenediamine tetra-acetate and used to determine a full blood count. Clotted samples were centrifuged within 12 hours of phlebotomy. The serum was transferred under aseptic conditions into $10 \mathrm{ml}$ sterile containers and frozen at 
Table 1 Essential clinical and laboratory variables in the 22 male and two female heavy drinkers

\begin{tabular}{|c|c|c|c|c|}
\hline Variable & $(n=)$ & Mean & Observed range & Reference values \\
\hline $\begin{array}{l}\text { Age (years) } \\
\text { Duration of excessive drinking (years) } \\
\text { Daily intake of alcohol (g) } \\
\text { AST (IU/l) } \\
\text { Alkaline phosphatase (IU/l) } \\
\text { GGT (IU/l) } \\
\text { Bilirubin (mmol/l) } \\
\text { Total CK (IU/l) } \\
\text { Total amylase (IU/l) } \\
\text { Amylase-P (IU/l) }\end{array}$ & $\begin{array}{l}24 \\
24 \\
24 \\
22 \\
22 \\
18 \\
22 \\
21 \\
21 \\
21\end{array}$ & $\begin{array}{c}45 \\
13 \\
333 \\
48 \cdot 9 \\
167 \cdot 7 \\
157 \cdot 1 \\
12 \cdot 3 \\
198 \\
111 \cdot 6 \\
41 \cdot 8\end{array}$ & $\begin{array}{c}23-68 \\
1-40 \\
140-750 \\
10-125 \\
107-399 \\
23-856 \\
6-18 \\
44-1371 \\
20-241 \\
0-113\end{array}$ & \multirow{3}{*}{$\begin{array}{l}0-25 \\
10-210 \\
0-37 \\
0-17 \\
<200 \\
<220 \\
\text { M } 35-115 \\
\text { F } 50-120 \\
<125 \\
\text { M } 13 \cdot 4-17 \cdot 0 \\
\text { F } 11 \cdot 9-15 \cdot 3 \\
82 \cdot 5-99 \cdot 0\end{array}$} \\
\hline $\begin{array}{l}\text { Amylase-S }(\mathrm{IU} / \mathrm{l}) \\
\text { Haemoglobin concentration }(\mathrm{g} / \mathrm{dl})\end{array}$ & $\begin{array}{l}21 \\
23\end{array}$ & $\begin{array}{l}68 \cdot 9 \\
15 \cdot 3\end{array}$ & $\begin{array}{l}9-207 \\
12 \cdot 0-17 \cdot 0\end{array}$ & \\
\hline Mean cell volume (fi) & 22 & $94 \cdot 3$ & $80-100$ & \\
\hline
\end{tabular}

$-20^{\circ} \mathrm{C}$ until required for biochemical and cytotoxicity studies.

Blood counts were performed using a Coulter Counter, model S plus IV (Coulter Electronics, Luton, Bedfordshire).

Aspartate transaminase (AST, EC 2.6.1.1), alkaline phosphatase (AP, EC 3.1.3.1), gamma-glutamyl transferase (GGT, EC 2.3.2.1) activities and bilirubin concentration were assayed on a Kone Progress Discretionary Analyser, using standard methods. Creatine kinase (CK, EC 2.7.3.2) was measured at $37^{\circ} \mathrm{C}$ by an optimised method ${ }^{14}$ with commercial reagents (CK-NAC opt.; BCL, Lewes, Sussex) using a centrifugal analyser (Encore, Baker Instruments). CK-MB activity was measured by electrophoresis and densitometric scanning. ${ }^{15}$ CK-MB concentration was determined using the Hybritech Tandem-E CK-MB assay system (Hybritech UK, Nottingham). This uses monoclonal antibodies to the $B$ and $M$ subunits in a two-site sandwich assay specific for CK-MB protein. The laboratory upper reference limits for these values were CK, $200 \mathrm{U} / 1$; CK-MB activity, $12 \mathrm{U} / 1$ and $5 \%$ of total CK; CK-MB concentration, $12 \mathrm{~g} / \mathrm{l}$. Total amylase (EC 3.2.11) was determined using Boehringer reagents (paranitrophenyl-malto-heptaoside) and amylase isoenzymes by the method of Foo and Rosalki. ${ }^{16}$

\section{CYTOTOXICITY STUDIES}

An aliquot of each serum sample was dialysed against $500 \mathrm{ml}$ of RPMl 1640 (Gibco Europe Ltd, Paisley, Scotland) containing $100 \mathrm{U}$ penicillin $/ \mathrm{ml}$ and $100 \mu \mathrm{g}$ streptomycin $/ \mathrm{ml}$ at $4^{\circ} \mathrm{C}$ for 24 hours. The cytotoxicity of both the undialysed and dialysed serum was tested against $A 9$ cells as described below.

In other experiments aliquots of each serum sample were incubated at $37^{\circ} \mathrm{C}$ for one hour with $1.6 \%(\mathrm{v} / \mathrm{v})$ of a solution containing $400 \mathrm{mmol} / 1 \mathrm{NaOH}$ or $400 \mathrm{mmol} / 1 \mathrm{NaOH}$ plus $10 \mathrm{mmol} / 1$ sodium boro- hydride $\left(\mathrm{NaBH}_{4}\right)$; the $\mathrm{pH}$ of both reaction mixtures was 9.5. After the incubation the mixtures were cooled on ice and dialysed against two $1000 \mathrm{ml}$ volumes of RPM1 1640 at $4^{\circ} \mathrm{C}$ over 24 hours. The dialysed solutions were tested for cytotoxic activity.

The cytotoxicity of the untreated and treated serum samples was assessed on the basis of their capacity to cause detachment of adherent mouse A9 cells, as described previously. ${ }^{3}$ The A9 cells were suspended to a concentration of $1.5 \times 10^{5} / \mathrm{ml}$ in Eagle's Minimum Essential Medium with Earle's salts and L-glutamine (Gibco Europe Ltd), $100 \mu \mathrm{g}$ streptomycin/ml, $100 \mathrm{U}$ penicillin $/ \mathrm{ml}$, and $10 \%(\mathrm{v} / \mathrm{v})$ fetal calf serum. Aliquots $(2 \mathrm{ml})$ of this cell suspension were placed within each of the wells of a 24-well tissue culture plate (Sterilin Ltd, Teddington, Middlesex) and the plates incubated at $37^{\circ} \mathrm{C}$ ( $5 \%$ carbon dioxide, $100 \%$ humidity) for six hours to permit the A9 cells to adhere. Non-adherent cells were removed and the adherent cells washed once with Hanks's solution at $37^{\circ} \mathrm{C}$. Equal volumes $(0.5 \mathrm{ml})$ of each serum sample to be tested and of RPM1 1640 (with penicillin and streptomycin) were placed within a well containing adherent cells and the culture plates incubated for 16 hours at $37^{\circ} \mathrm{C}(5 \%$ carbon dioxide, $100 \%$ humidity). The wells were then emptied and the residual adherent cells washed once with Hanks's solution at $37^{\circ} \mathrm{C}$. The adherent cells were detached by treatment with $1 \mathrm{ml} 0 \cdot 1 \%(\mathrm{w} / \mathrm{v})$ lyophilised trypsin (Gibco Europe Ltd) in calcium and magnesium-free phosphate buffered saline. When all the cells were detached, the trypsin was neutralised by the addition of $200 \mu \mathrm{l}$ newborn calf serum to each well. The cells present in $1 \mathrm{ml}$ of the cell suspension were counted after dilution with $9 \mathrm{ml}$ Isoton (Coulter Electronics Ltd), using a Coulter Counter, Model ZF (Coulter Electronics Ltd) and the total number of residual adherent cells in each well calculated.

The extent of cytotoxicity of a serum sample was considered to be inversely proportional to the number 
of residual adherent A9 cells (NRAC) after exposure to the sample being tested. Another index of cytotoxicity was derived from the experiments in which serum was treated with $\mathrm{NaOH}$ or $\mathrm{NaOH}$ plus $\mathrm{NaBH}_{4}$ and was based on evidence that treatment with $\mathrm{NaBH}_{4}$ (pH 9.5) results in detoxification of post-alcohol serum because of the reduction and consequent stabilisation of cytotoxic unstable Schiff bases formed between acetaldehyde and proteins. ${ }^{13}$ This index, termed the "percentage increase in residual adherent cells", was determined by subtracting the NRAC in the presence of $\mathrm{NaOH}$ from the NRAC in the presence of $\mathrm{NaOH}$ plus $\mathrm{NaBH}_{4}$ and expressing the difference as a percentage of the NRAC in the presence of $\mathrm{NaOH}$. The cytotoxicity of a serum sample was considered to be directly proportional to the percentage increase in residual adherent cells (PIRAC).

When both variables to be correlated were normally distributed, Pearson's correlation coefficient (r) was determined. When this was not the case, Spearman's correlation coefficient $(R)$ was calculated.

\section{Results}

Table 1 summarises the clinical and laboratory data in the patients studied. All had consumed an average of $140 \mathrm{~g}$ ethanol or more a day for at least one year. None of the patients showed clinical evidence of chronic liver disease. AST, GGT, alkaline phosphatase, total CK and amylase activities were raised in $63 \%(14 / 22)$, $66 \%(12 / 18), 18 \%(4 / 22), 13 \%(3 / 23)$ and $17 \%(4 / 23)$ of cases, respectively. The serum bilirubin concentration was raised in only one of the 22 patients investigated. The haemoglobin concentration was within the normal range except in two male patients in whom it was slightly reduced. None of the patients had reticulocytosis.

Isoenzyme studies showed only CK-MM activity (the skeletal muscle isoenzyme form) in all cases except one, in which $95 \%$ of the total CK activity consisted of CK-MM and $5 \%$ of CK-MB (CK-MB $\geqslant 5 \%$ of total CK suggests cardiac damage). All the patients with increased amylase activity showed an increase in isoamylase-S but not in isoamylase- $P$, indicating that the salivary gland rather than pancreas was the source of this increase.

Correlations were sought between NRAC with undialysed serum, NRAC with dialysed serum, or PIRAC on the one hand, and the various variables listed in table 1 (except age and duration of drinking) on the other. The only significant correlations observed are given in table 2 , and two of these are illustrated in figs 1 and 2. The strongest correlation seen was between PIRAC and AST ( $r=0.814$; fig 2), the variability in PIRAC accounting for $64 \%$ of the variability in AST. Table 2 also gives details of the few significant correlations observed between the various biochemical variables estimated.

\section{Discussion}

In heavy drinkers there is a remarkably strong and highly significant correlation between PIRAC and AST. There are less strong but significant correlations between NRAC with undialysed or dialysed serum and AST. As both NRAC and, particularly, PIRAC reflect the cytotoxic activity of serum proteins modified by acetaldehyde, these correlations point to a direct or indirect relation between the concentration of such proteins and damage to one or more cell types

Table 2 Pearson correlation coefficients ( $r$ ) or Spearman correlation coefficients $(R)$ for all significant relations observed between various variables in heavy drinkers

\begin{tabular}{|c|c|c|c|c|c|}
\hline \multicolumn{2}{|l|}{ Coordinates } & \multirow[b]{2}{*}{$(n=)$} & \multirow[b]{2}{*}{$r$} & \multirow[b]{2}{*}{$R$} & \multirow[b]{2}{*}{ p Value } \\
\hline$x$ & $y$ & & & & \\
\hline Residual A9 cells with undialysed serum & AST & 22 & $\begin{array}{l}-0.435 \\
-0.434\end{array}$ & & $\begin{array}{l}0.043 \\
0.049\end{array}$ \\
\hline Residual A9 cells with dialysed serum & AST & 22 & $\begin{array}{l}-0.569 \\
-0.562\end{array}$ & & 0.006 \\
\hline $\begin{array}{l}\text { Percentage increase in residual } A 9 \text { cells } \\
\text { after borohydride treatment }\end{array}$ & $\begin{array}{l}\text { AST } \\
\text { Total CK }\end{array}$ & $\begin{array}{l}22 \\
21^{*} \\
21 \\
19^{*}\end{array}$ & $\begin{array}{l}0.814 \\
0.801\end{array}$ & $\begin{array}{l}0.564 \\
0.480\end{array}$ & $\begin{array}{l}0.0001 \\
0.001 \\
0.008 \\
0.037\end{array}$ \\
\hline AST & $\begin{array}{l}\text { GGT } \\
\text { Bilirubin }\end{array}$ & $\begin{array}{l}18+ \\
22 \\
21 *\end{array}$ & $\begin{array}{l}-0.482 \\
-0.468\end{array}$ & 0.734 & $\begin{array}{l}0.005 \\
0.023\end{array}$ \\
\hline & AP & 22 & & $\begin{array}{l}0.598 \\
0.546\end{array}$ & $\begin{array}{l}0.032 \\
0.003 \\
0.010\end{array}$ \\
\hline GGT & $\begin{array}{l}\text { Amylase } \\
\text { AP }\end{array}$ & $\begin{array}{l}15+ \\
18 \dagger\end{array}$ & & $\begin{array}{l}0.624 \\
0.674\end{array}$ & $\begin{array}{l}0.013 \\
0.002\end{array}$ \\
\hline
\end{tabular}

*Excluding female patients.

$\dagger$ No data available for female patients. 


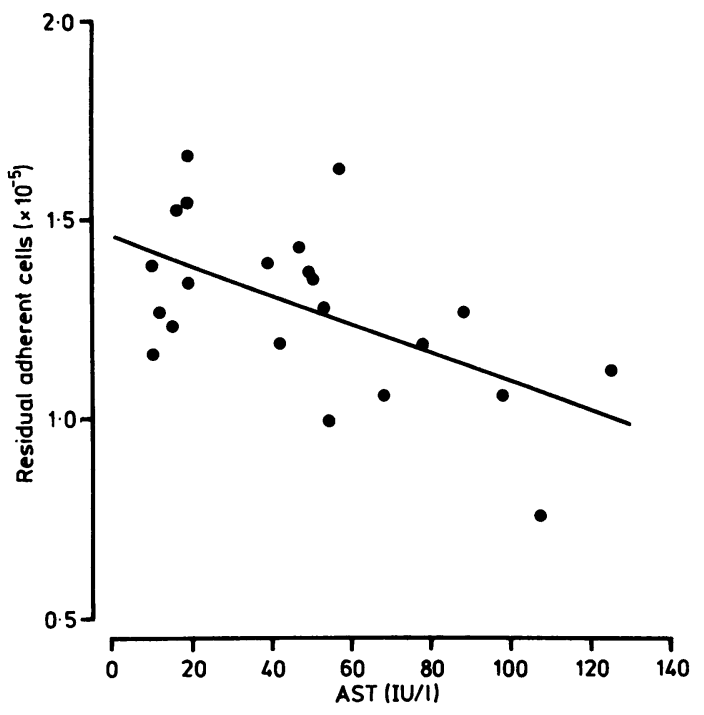

Fig 1 Correlation between serum AST activity in heavy drinkers and number of residual adherent cells after incubation of $A 9$ cells with dialysed serum $(r=-0.569)$.

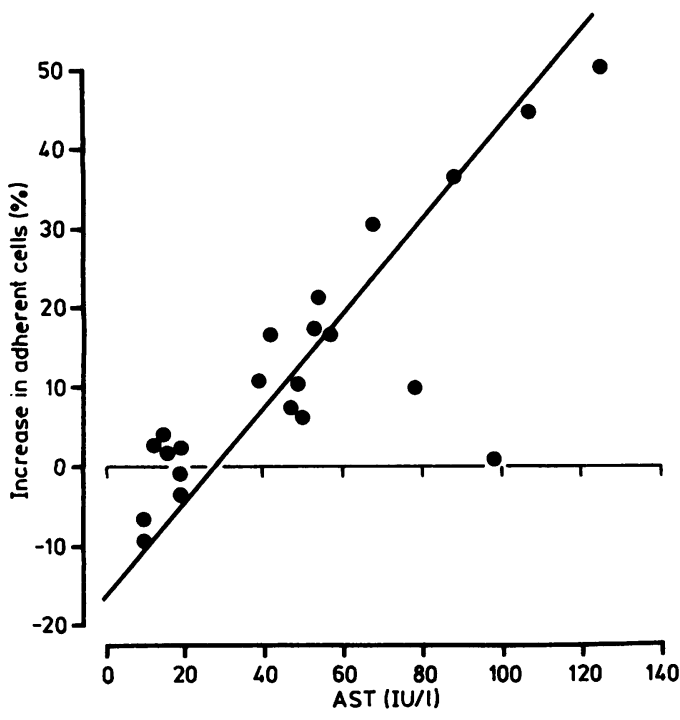

Fig 2 Correlation between serum AST activity in heavy drinkers and percentage increase in residual adherent $A 9$ cells after treatment of serum with $\mathrm{NaBH}_{4}(r=0.814)$.

containing AST. Cells which release AST when injured are hepatocytes, cardiac and skeletal muscle cells, and erythrocytes. As only one of the cases studied had raised CK-MB activities and only two cases showed increased CK-MM activities, it seems unlikely that damaged cardiac or skeletal muscle cells were the major source of the increased AST activities in the sera of our patients. It is also unlikely that damage to circulating red cells was an important source of serum AST as no patient showed haematological or biochemical evidence suggestive of a substantial degree of haemolysis. For these reasons, and because there was a highly significant correlation between AST and GGT, we conclude that the high serum AST activities observed in our patients were largely derived from hepatocytes and that our data show some association between the concentrations of circulating cytotoxic protein and hepatocellular injury. As there is probably a close relation between the quantity of free acetaldehyde released into the hepatic sinusoids and the concentrations of circulating cytotoxic protein, our data point to a strong correlation between AST and hepatic acetaldehyde generation. This correlation may merely result from the fact that both AST and acetaldehyde are released at an increased rate from damaged hepatocytes. Alternatively, the observed correlations may represent evidence of the hepatotoxicity of acetaldehyde generated in the liver. Up to now the hypothesis that acetaldehyde is hepatotoxic has been based largely on evidence from in vitro studies. ${ }^{17-22}$

Previous workers have found increased amounts of conjugated dienes in the plasma and liver in chronic alcoholics and have suggested that free radical activity may have a role in the pathogenesis of liver damage induced by alcohol. ${ }^{123}$ The increased free radical activity in the livers of heavy drinkers, however, does not correlate either with serum AST activity or the concentration of glutathione-S transferase, a sensitive marker of liver damage (RS Fink et al, unpublished observations). The present finding that concentrations of serum proteins made cytotoxic by acetaldehyde correlate with serum AST is, therefore, especially interesting.

Despite the fact that only three of the 23 cases had raised total CK activities, there was a relatively weak but significant correlation between PIRAC and total CK (largely CK-MM). This raises the possibility that modified serum proteins have a toxic effect on skeletal muscle cells in vivo. Thus our data suggest that both acetaldehyde and serum proteins modified by acetaldehyde have a role in causing tissue damage in alcoholics.

This work was supported in part by a grant from the Wellcome Trust. We are grateful to Mr G Barden for invaluable technical assistance, Dr J Spencer-Peet for carrying out the general biochemical tests, and Dr AY Foo for assistance with the isoenzyme studies.

\section{References}

1 Rognstad R, Grunnet N. Enzymatic pathways of ethanol metabolism. In: Majchrowicz E, Noble EP, eds. Biochemistry and 
pharmacology of ethanol. Vol 1. New York: Plenum, 1979: 65-85.

2 Wickramasinghe SN. Rates of metabolism of ethanol to acetate by human neutrophil precursors and macrophages. Alcohol Alcohol 1985;20:299-303.

3 Wickramasinghe SN. Supernatants from ethanol-containing macrophage cultures have cytotoxic activity. Alcohol Alcohol 1986;21:263-8.

4 Wickramasinghe SN, Barden G, Levy L. The capacity of macrophages from different murine tissues to metabolise ethanol and generate an ethanol-dependent non-dialysable cytotoxic activity in vitro. Alcohol Alcohol 1987;22:31-9.

5 Wickramasinghe SN. Role of macrophages in the pathogenesis of alcohol induced tissue damage. Br Med J 1987;294:1137-9.

6 Thomas M, Peters TJ. Acetaldehyde: its role in alcoholic toxicity and dependence. $\mathrm{Br}$ J Addict 1981;76:375-8.

7 Eriksson CJP. The role of acetaldehyde in drinking behaviour and tissue damage. British Journal on Alcohol and Alcoholism 1982;17:57-69.

8 Feierman DE, Winston GW, Cederbaum AI. Ethanol oxidation by hydroxy radicals: role of iron chelates, superoxide, and hydrogen peroxide. Alcoholism: Clinical and Experimental Research 1985;9:95-102.

9 Lewis KO, Paton A. Could superoxide cause cirrhosis? Lancet 1982;ii:188-9.

10 Fink R, Marjot DH, Cawood P, Norden AG, Dormandy TL. Increased free-radical activity in chronic alcoholics. Life Chemistry Reports 1985;3:199-202.

11 MacSween RNM, Anthony RS. Immune mechanisms in alcoholic liver disease. In: Hall P, ed. Alcoholic liver disease. London: Edward Arnold, 1985:69-89.

12 Wickramasinghe SN, Gardner B, Barden G. Cytotoxic protein molecules generated as a consequence of ethanol metabolism in vitro and in vivo. Lancet 1986;ii:823-6.

13 Wickramasinghe SN, Gardner B, Barden G. Circulating cytotoxic protein generated after ethanol consumption: identification and mechanism of reaction with cells. Lancet 1987;ii:122-6.
14 Rosalki SB. Association of Clinical Biochemist's Working Party Recommendations: proposed methods for determinations of some enzymes in blood serum. Association of Clinical Biochemists News Sheet 1980;(Supplement):37-9.

15 Rosalki SB. Creatine kinase isoenzyme demonstration and measurement. ACP Broadsheet 106. London: BMA, ACP, 1982.

16 Foo Y, Rosalki SB. Isoenzymes of $\alpha$-amylase. In: Bergmeyer HU, ed. Methods of enzymatic analysis. 3rd Ed, Vol 4. Weinheim: Verlag Chemie, 1984:167-77.

17 Cederbaum AI, Lieber CS, Rubin E. The effect of acetaldehyde on mitochondrial function. Arch Biochem Biophys 1974;161:26-39.

18 Burke JP, Rubin E. The effects of ethanol and acetaldehyde on the products of protein synthesis by liver mitochondria. Lab Invest 1979;41:393-400.

19 Schreiber SS, Oratz M, Rothschild MA, Reff F, Evans C. Alcoholic cardiomyopathy. II. The inhibition of cardiac microsomal protein synthesis by acetaldehyde. $\mathrm{J} \mathrm{Mol} \mathrm{Cell}$ Cardiol 1974;6:207-13.

20 Perin A, Scalabrino G, Sessa A, Arnaboldi A. In vitro inhibition of protein synthesis in rat liver as a consequence of ethanol metabolism. Biochim Biophys Acta 1974;366:101-8.

21 Tuma DJ, Zetterman RK, Sorrell MF. Inhibition of glycoprotein secretion by ethanol and acetaldehyde in rat liver slices. Biochem Pharmacol 1980;29:35-8.

22 Wickramasinghe SN, Malik F. Acetaldehyde causes a prolongation of the doubling time and an increase in the modal volume of cells in culture. Alcoholism: Clinical and Experimental Research 1986;10:350-4.

23 Shaw S, Rubin K, Lieber CS. Depressed hepatic glutathione and increased diene conjugates in alcoholic liver disease. Evidence of lipid peroxidation. Dig Dis Sci 1983;28:585-9.

Requests for reprints to: Professor S N Wickramasinghe, Department of Haematology, St Mary's Hospital Medical School, London W2 1PG, England. 